\title{
Pulmonary gas exchange in elderly subjects
}

\author{
H. Guénard, R. Marthan
}

Pulmonary gas exchange in elderly subjects. H. Guénard, R. Marthan. (CERS Journals Ltd 1996.

ABSTRACT: Although important alterations in structure and function develop with age, the hypothesis that the lungs are capable of maintaining adequate gas exchange for the maximum human life span is generally accepted.

This hypothesis was examined by measuring arterial oxygen and carbon dioxide tension $\left(\mathrm{Pa}_{\mathrm{a}} \mathrm{O}_{2}\right.$ and $\left.\mathrm{Pa}, \mathrm{CO}_{2}\right)$ alveolo-arterial differences in oxygen and carbon dioxide tension $\left(\mathrm{P}_{\mathrm{A}-\mathrm{a}, \mathrm{O}_{2}}\right.$ and $\left.\mathrm{Pa}-\mathrm{A}, \mathrm{CO}_{2}\right)$, steady state transfer capacity of the lung for carbon monoxide $\left(T_{\mathrm{L}}, \mathrm{CO}, \mathrm{ss}\right)$ as well as the gas exchange ratio $(\mathrm{R})$ in a series of 74 healthy subjects aged more than 68 yrs (69-104 yrs). In addition, $P \mathrm{a}_{2} \mathrm{O}_{2}$ and $P \mathrm{P}, \mathrm{CO}_{2}$ were measured in a series of 55 young healthy subjects, who acted as controls.

In the elderly subjects, except for $T \mathrm{~L}, \mathrm{CO}$,ss, there was no significant correlation between any of the other variables and age. However, for a given $\mathrm{Pa}_{\mathrm{a}} \mathrm{CO}_{2}, \mathrm{~Pa}, \mathrm{O}_{2}$ was always lower in the group of elderly subjects than in the group of young control

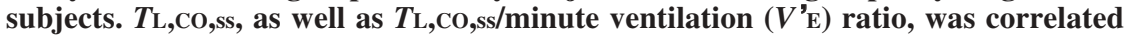
with age, according to the following regression equations: $T \mathrm{~L}, \mathrm{CO}, \mathrm{ss}\left(\mathrm{mL} \cdot \mathrm{min}^{-1} \cdot \mathrm{kPa}^{-1}\right)$ $=126-0.90 \times$ age $(\mathrm{yrs})$, and $T_{\mathrm{L}, \mathrm{Co}, \mathrm{ss} /} V^{\prime} \mathrm{E}\left(\mathrm{kPa}^{-1} \times \mathbf{1 0}^{3}\right)=13.5-0.085 \times$ age, respectively.

These results show that arterial oxygen tension did not decrease with age in this series of elderly subjects. However, the decrease in steady-state transfer capacity of the lungs for carbon monoxide with age indicates that oxygen transport could be diffusion-limited in elderly subjects, at least when oxygen consumption is increased.

Eur Respir J., 1996, 9, 2573-2577
Laboratoire de Physiologie, Université de Bordeaux II, Bordeaux, France.

Correspondence: H. Guénard Laboratoire de Physiologie

Faculté de Médecine Victor Pachon

Université de Bordeaux II

146 rue Léo Saignat

33076 Bordeaux cedex

France

\section{Keywords: Ageing}

alveolo-arterial differences

blood gases,

carbon monoxide transfer capacity

Received: January 171995

Accepted after revision July 181996
Ageing is usually thought to be accompanied by a progressive decline in arterial oxygen tension $\left(\mathrm{Pa}, \mathrm{O}_{2}\right)$ and transfer capacity of the lungs for carbon monoxide $(T \mathrm{~L}, \mathrm{CO})$ [1]; whereas, arterial carbon dioxide tension $\left(\mathrm{Pa}_{\mathrm{a}, \mathrm{CO}_{2}}\right)$ remains constant [2] and ventilation meets, at least at rest, the $\mathrm{CO}_{2}$ excretion demand. However, data establishing these relationships are often either obtained in small samples of aged subjects or extrapolated from those measured in younger subjects. Therefore, it seemed of interest to measure gas exchange in a large sample of aged healthy subjects to avoid any extrapolation. From these data, the possibility of a limitation in lung $\mathrm{O}_{2}$ transport as well as its determinants could be examined.

\section{Methods}

\section{Subjects}

Seventy four subjects aged more than 68 yrs (range 69-104 yrs) were selected for this study. Two thirds of this population were female (table 1). The mean age was 82 yrs. The subjects were recruited from a retirement home with the assistance of the local consultant physician, who reviewed their medical record. None of them had a history of chronic or acute pulmonary or cardiac disease, none of the females was a smoker or ex-smoker, but 16 out of 25 of the males were ex-smokers. They were all able-bodied and did not suffer from obesity. At
Table 1. - Age, weight and body skin area of the population studied

\begin{tabular}{lccc}
\hline & \multicolumn{1}{c}{$\begin{array}{c}\text { Age } \\
\text { yrs }\end{array}$} & $\begin{array}{c}\text { Weight } \\
\mathrm{kg}\end{array}$ & $\begin{array}{c}\text { Body skin area } \\
\mathrm{m}^{2}\end{array}$ \\
\hline $\begin{array}{l}\text { Female }(\mathrm{n}=49) \\
\text { Male }(\mathrm{n}=25)\end{array}$ & $\begin{array}{l}82(69-104) \\
81(70-97)\end{array}$ & $53(32-84)$ & $1.47(1.39-1.74)$ \\
\hline
\end{tabular}

Values are presented as mean, and range in parenthesis.

the time of the study, their complete physical examination, chest radiograph and electrocardiogram were within the normal range. All of the subjects gave informed consent. All measurements were performed on subjects in the sitting position, breathing quietly in steady state. All measurements needing a forced manoeuvre were excluded to avoid the bias of poor co-operation, which is an age-dependent factor [3].

\section{Protocol}

The measured data, including steady state transfer capacity of the lung for carbon monoxide ( $T \mathrm{~L}, \mathrm{CO}, \mathrm{ss})$, $\mathrm{Pa}, \mathrm{O}_{2}, \mathrm{~Pa}_{\mathrm{a}} \mathrm{CO}_{2}, \mathrm{pH}$, alveolo-arterial differences in oxygen and carbon dioxide tension $P_{\mathrm{A}-\mathrm{a}, \mathrm{O}_{2}}$ and $\mathrm{Pa}-\mathrm{A}, \mathrm{CO}_{2}$, were obtained as follows. The subject was first asked to breath normally through a mouthpiece connected to a low resistance valve $\left(0.25 \mathrm{hPa}\right.$ pressure loss for $\left.0.25 \mathrm{~L} \cdot \mathrm{s}^{-1}\right)$ with a Fleisch No. 2 pneumotachograph (PTG) $(0.08 \mathrm{hPa}$ 
pressure loss for $0.25 \mathrm{~L} \cdot \mathrm{s}^{-1}$ ) on the expiratory arm. After a 5 min adaptation period, the inspiratory arm of the valve was connected via a two-way tap, to a rubber bag filled with a mixture of $21 \% \mathrm{O}_{2}$ and $0.1 \% \mathrm{CO}$ in $\mathrm{N}_{2}$. The subject breathed quietly for another 5 min. Tidal volume $\left(V_{\mathrm{T}}\right)$ and instantaneous expired $\mathrm{CO}$ fraction $(F \mathrm{E}, \mathrm{CO})$ (Cosma Rubis 3000 France) were displayed on a graphic recorder (HP 740A, USA) for 2 min. Meanwhile, expired gas was collected in a rubber bag $(50 \mathrm{~L})$ and later analysed for $F \mathrm{E}$, CO. After calibration of the recorded parameters, $V_{\mathrm{T}}$ as well as mean alveolar carbon monoxide tension $(P \mathrm{~A}, \mathrm{CO})$ were calculated. $P \mathrm{~A}, \mathrm{CO}$ was taken as the mid-plateau value of the instantaneous $P_{\mathrm{CO}}$ recording. Mean $P \mathrm{~A}, \mathrm{CO}, V_{\mathrm{T}}$ and respiratory frequency $\left(f_{\mathrm{R}}\right)$ were calculated during the $2 \mathrm{~min}$ of analysis. From these data, minute ventilation $\left(V^{\prime} \mathrm{E}\right), \mathrm{CO}$ consumption $\left(V^{\prime} \mathrm{CO}\right)$ and $T \mathrm{~L}, \mathrm{CO}, \mathrm{ss}$ were derived. At completion of $T \mathrm{~L}, \mathrm{CO}, \mathrm{ss}$ measurement, the subject was allowed to rest for $10 \mathrm{~min}$. An arterial blood sample was then slowly withdrawn from the humeral artery and analysed for $\mathrm{Pa}, \mathrm{O}_{2}, \mathrm{~Pa}_{\mathrm{a}} \mathrm{CO}_{2}$ and $\mathrm{pH}$ with an IL 613 analyser (Instruments Laboratory, USA), which was calibrated before each measurement. Simultaneously, instantaneous expired $\mathrm{O}_{2}$ (Beckman OM11, USA) and $\mathrm{CO}_{2}$ fractions (Jaeger $\mathrm{CO}_{2}$ test, Germany) were recorded to measure alveolar oxygen and carbon dioxide tensions $\left(\mathrm{Pa}, \mathrm{O}_{2}\right.$ and $\left.\mathrm{Pa}_{\mathrm{a}} \mathrm{CO}_{2}\right)$. Meanwhile, expired gas was collected for later analysis of $\mathrm{O}_{2}$ and $\mathrm{CO}_{2}$ fractions. Respiratory gas exchange ratio $(\mathrm{R}), \mathrm{PA}_{\mathrm{A}}, \mathrm{O}_{2}$ and $\mathrm{Pa}-\mathrm{A}, \mathrm{CO}_{2}$ were also calculated.

\section{Control group}

To provide reference values for blood gas tensions measured using the same techniques as in the laboratory, blood gas values were obtained in a series of 55 young healthy subjects. Medical students aged $26 \pm 4 \mathrm{yrs}$, registered for a postgraduate course in physiology, acted as control subjects. In order to mimic the actual ventilatory condition observed in the elderly subjects, 20 of these control subjects were asked to slightly hyperventilate, so that their $\mathrm{Pa}_{\mathrm{a}} \mathrm{CO}_{2}$ value ranged $4-4.5 \mathrm{kPa}$ (see Results).

\section{Statistical analysis}

Linear regressions were calculated between main gas exchange data and age using a robust regression software (NCSS, USA). Statistical significance was accepted at the $95 \%$ confidence level $(\mathrm{p}<0.05)$. Mean $\mathrm{Pa}_{\mathrm{a}} \mathrm{O}_{2}$ values between elderly and control subjects were compared using unpaired Student's t-test, and a p-value of 0.05 was considered significant.

\section{Results}

Table 2 presents mean values of the main gas exchange data in the elderly subjects. In $77 \%$ of the subjects, gas exchange ratio (R-values) were $0.7-1$. As expected, some subjects (19\%) had a trend to hyperventilate when connected to the mouth piece as shown by R-values above 1. Three subjects (4\%) had R-values below 0.7 and were suspected of hypoventilating.

Neither $\mathrm{Pa}, \mathrm{O}_{2}$ nor $\mathrm{Pa}, \mathrm{CO}_{2}$ were correlated with age in the group of elderly subjects (fig. 1 ). There was also no correlation between either $P \mathrm{~A}-\mathrm{a}, \mathrm{O}_{2}$ or $P \mathrm{a}-\mathrm{ACO}_{2}$ and age (fig. 2).
Table 2. - Main gas exchange data in elderly subjects

\begin{tabular}{|c|c|}
\hline${\mathrm{Pa}, \mathrm{O}_{2} \mathrm{kPa}}$ & $11.2 \pm 1.0$ \\
\hline 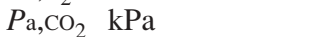 & $4.6 \pm 0.6$ \\
\hline$P_{\mathrm{A}-\mathrm{a}, \mathrm{O}_{2}} \mathrm{kPa}$ & $4.4 \pm 1.3$ \\
\hline$P \mathrm{a}-\mathrm{A}, \mathrm{CO}_{2} \quad \mathrm{kPa}$ & $0.7 \pm 0.4$ \\
\hline$T \mathrm{~L}, \mathrm{CO}, \mathrm{ss} \mathrm{mL} \cdot \mathrm{min}^{-1} \cdot \mathrm{kPa}^{-1}$ & $53.9 \pm 16.3$ \\
\hline$V^{\prime} \mathrm{O}_{2} \mathrm{~mL} \cdot \mathrm{min}^{-1}$ & $215.4 \pm 49.6$ \\
\hline$V^{\prime} \mathrm{CO}_{2} \mathrm{~mL} \cdot \mathrm{min}^{-1}$ & $186.7 \pm 47.2$ \\
\hline $\mathrm{R}$ & $0.83 \pm 0.27$ \\
\hline
\end{tabular}

Values are presented as mean \pm SD. $P \mathrm{a}, \mathrm{O}_{2}:$ arterial oxygen tension; $P \mathrm{a}, \mathrm{CO}_{2}:$ arterial carbon dioxide tension; $P \mathrm{~A}-\mathrm{a}, \mathrm{O}_{2}:$ alveoloarterial difference in oxygen tension; $P \mathrm{a}-\mathrm{ACO}_{2}$ : alveolo-arterial difference in carbon dioxide tension; $T \mathrm{~L}, \mathrm{CO}, \mathrm{ss}$ : steady-state transfer capacity of the lung for carbon monoxide; $V^{\prime} \mathrm{O}_{2}$ : oxygen consumption; $V^{\prime} \mathrm{CO}_{2}$ : carbon dioxide production; R: gas exchange ratio.

$P a, \mathrm{O}_{2}$ values are compared between the young and elderly subjects in table 3 . As mentioned above, to take into account the ventilatory status of the subjects, the comparison was performed according to the $\mathrm{Pa}, \mathrm{CO}_{2}$ value. In both series of subjects (i.e. young and elderly), three groups of an approximately similar size were characterized as follows: $P$ a, $\mathrm{CO}_{2} 4-4.5 \mathrm{kPa} ; P \mathrm{a}, \mathrm{CO}_{2} 4.5-5 \mathrm{kPa}$; and $P \mathrm{a}, \mathrm{CO}_{2}$ $>5 \mathrm{kPa}$. The very few subjects whose $P \mathrm{a}, \mathrm{CO}_{2}$ was lower

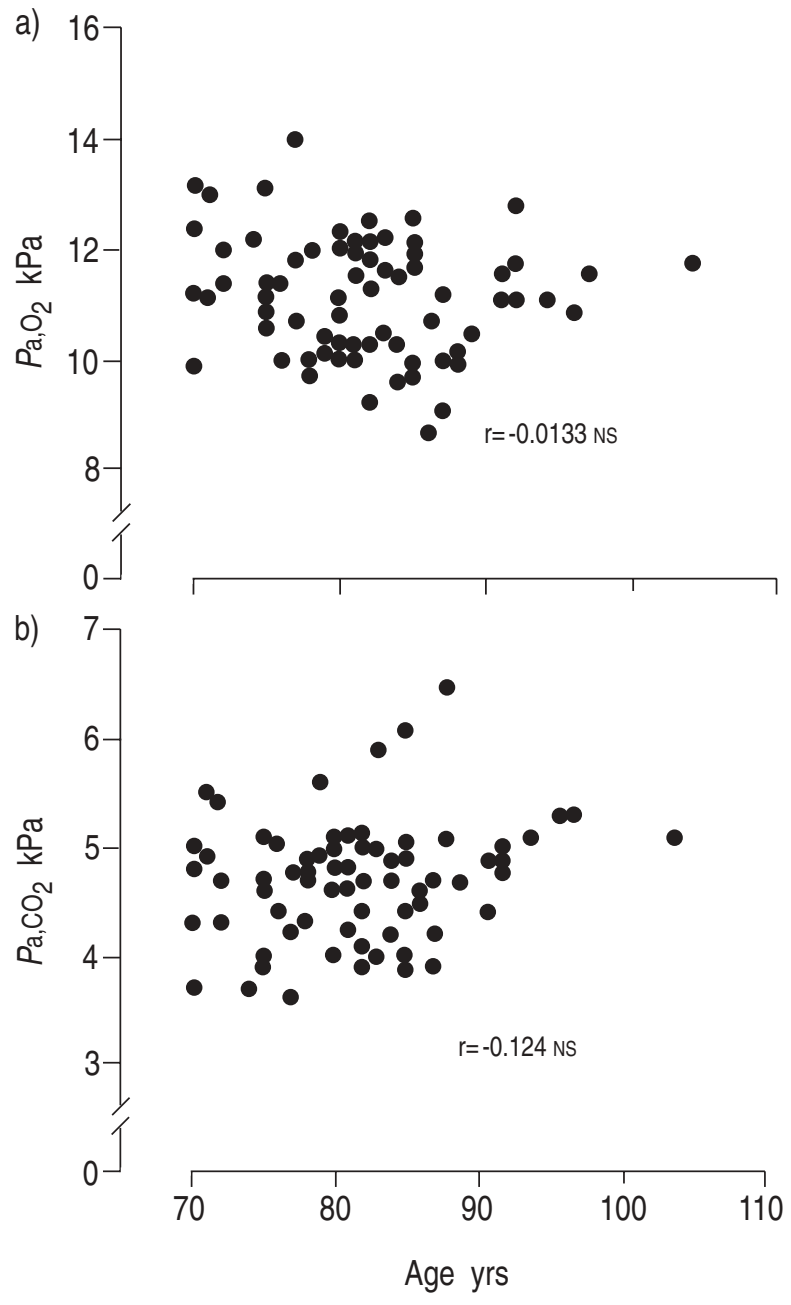

Fig. 1. - a) $P$ a, $\mathrm{O}_{2}$; and b) $P$ a, $\mathrm{CO}_{2}$ as a function of age. The solid lines indicate the regression lines according to equations in each graph. There was no correlation between arterial blood gas tensions and age. $\mathrm{Pa}_{\mathrm{a}} \mathrm{O}_{2}$ : arterial oxygen tension; $\mathrm{Pa}_{\mathrm{a}} \mathrm{CO}_{2}$ : arterial carbon dioxide tension. 

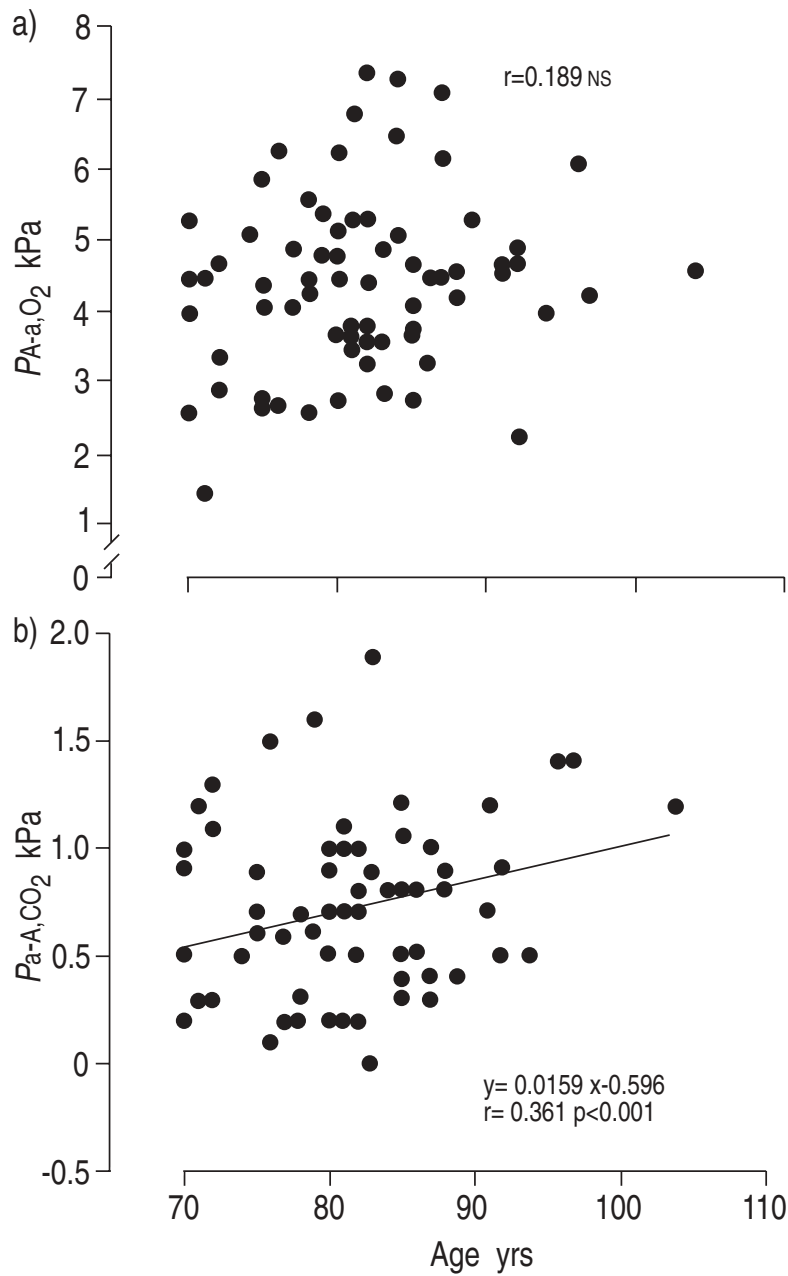

Fig. 2. - a) Alveolo-arterial difference in oxygen tension $\left(P_{\mathrm{A}-\mathrm{a}, \mathrm{O}_{2}}\right)$; and b) alveolo-arterial difference in carbon dioxide tension $\left(P \mathrm{a}-\mathrm{ACO}_{2}\right)$ as a function of age. The solid line indicates the regression line according to the equation in the graph.

than $4 \mathrm{kPa}$ were discarded (four individuals in both series). Table 3 shows that $P \mathrm{a}, \mathrm{O}_{2}$ was always significantly lower in the elderly than in the young subjects, whatever the range of $P \mathrm{a}, \mathrm{CO}_{2}$. This table also shows that, unlike young subjects, in the elderly the $P \mathrm{a}, \mathrm{O}_{2}$ did not increase with the decrease in $\mathrm{Pa}_{\mathrm{a}} \mathrm{CO}_{2}$. As a consequence, for the group with the highest $P \mathrm{a}, \mathrm{CO}_{2}$ values (i.e. $\left.>5 \mathrm{kPa}\right)$, the difference in $\mathrm{Pa}, \mathrm{O}_{2}$ between the elderly and young subjects was

Table 3. - $\mathrm{Pa}_{\mathrm{a}, \mathrm{O}_{2}}$ values $(\mathrm{kPa})$ in the two populations studied subdivided into three subgroups according to $\mathrm{Pa}, \mathrm{CO}_{2}$ values

\begin{tabular}{lccc}
\hline & \multicolumn{3}{c}{$P \mathrm{a}, \mathrm{CO}_{2}$} \\
\cline { 2 - 4 } & $4-4.5 \mathrm{kPa}$ & $4.5-5 \mathrm{kPa}$ & $>5 \mathrm{kPa}$ \\
\hline $\begin{array}{l}\text { Elderly (n=70) } \\
P \mathrm{a}, \mathrm{O}_{2} \mathrm{kPa}\end{array}$ & $\begin{array}{c}11.4 \pm 1.16 \\
(\mathrm{n}=20)\end{array}$ & $\begin{array}{c}10.9 \pm 0.97 \\
(\mathrm{n}=27)\end{array}$ & $\begin{array}{c}11.2 \pm 0.82 \\
(\mathrm{n}=23)\end{array}$ \\
$\begin{array}{l}\text { Young }(\mathrm{n}=51) \\
P \mathrm{a}, \mathrm{O}_{2} \mathrm{kPa}\end{array}$ & $\begin{array}{c}13.6 \pm 1.27 \\
(\mathrm{n}=19)\end{array}$ & $\begin{array}{c}12.9 \pm 1.08 \\
(\mathrm{n}=17)\end{array}$ & $\begin{array}{c}11.8 \pm 0.96 \\
(\mathrm{n}=15)\end{array}$ \\
\hline p-value & $<0.001$ & $<0.01$ & $<0.05$ \\
\hline
\end{tabular}

Values are presented as mean \pm SD. The last line indicates the p-value (unpaired Student's t-test) between mean $\mathrm{Pa}, \mathrm{O}_{2}$ in the elderly and young for each $\mathrm{Pa}_{\mathrm{a}} \mathrm{CO}_{2}$ subgroup. $\mathrm{Pa}, \mathrm{O}_{2}$ : arterial oxygen tension; $\mathrm{Pa}, \mathrm{CO}_{2}$ : arterial carbon dioxide tension.
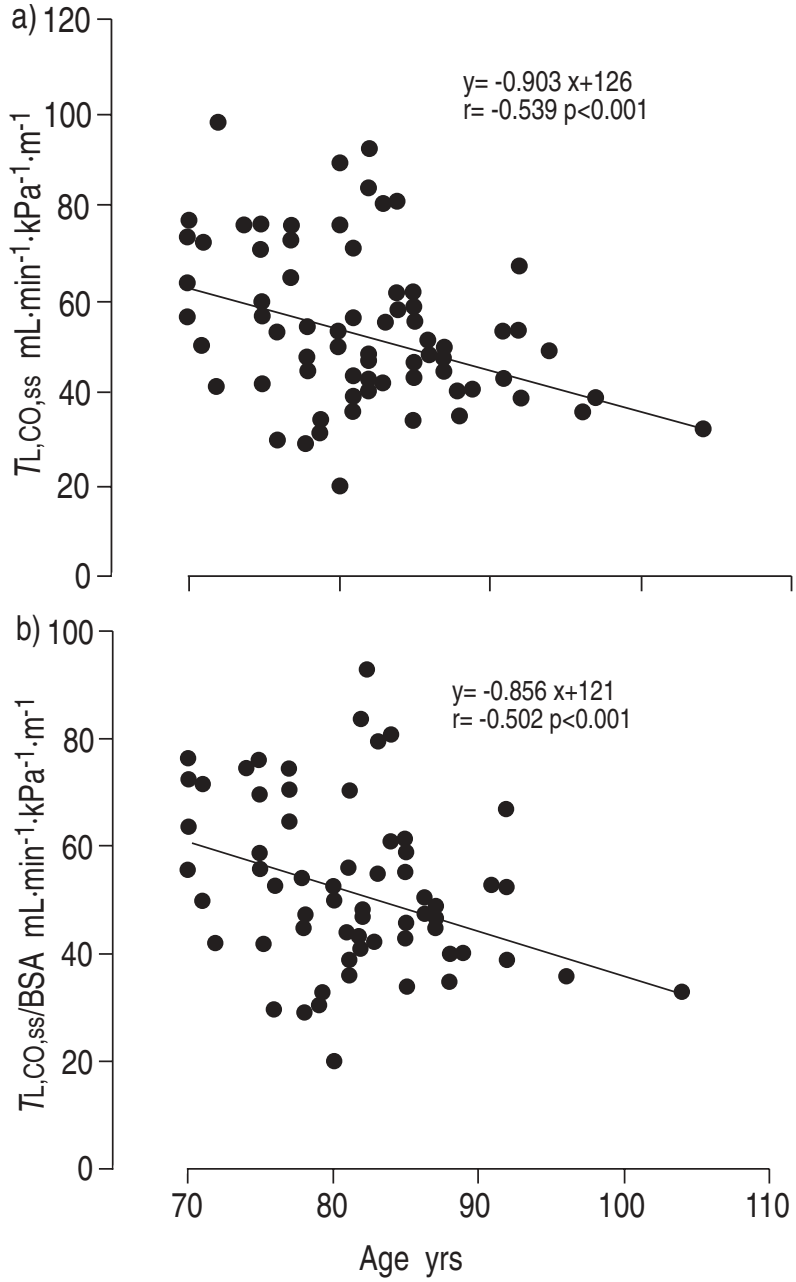

Fig. 3. - $T_{\mathrm{L}, \mathrm{CO}, \mathrm{ss}}$ and $T \mathrm{~L}, \mathrm{CO}, \mathrm{ss} / \mathrm{BSA}$ as function of age. The solid lines indicate the regression lines according to equations in each graph. $T \mathrm{~L}, \mathrm{CO}$,ss was negatively correlated to age. $T \mathrm{~L}, \mathrm{CO}$,ss: steady-state transfer capacity of the lungs for carbon monoxide; $T \mathrm{~L}, \mathrm{CO}, \mathrm{ss} / \mathrm{BSA}$ : ratio of $T_{\mathrm{L}, \mathrm{CO}, \mathrm{ss}}$ to body surface area.

very small (approximately $0.6 \mathrm{kPa}$ ), although significant.

$T \mathrm{~L}, \mathrm{CO}$,ss decreased significantly with age, although the results were scattered (fig. 3 ). The linear regression equation was: $T \mathrm{~L}, \mathrm{CO}, \mathrm{ss}\left(\mathrm{mL} \cdot \mathrm{min}^{-1} \cdot \mathrm{kPa}^{-1}\right)=126-0.90 \times$ age $(\mathrm{yrs})$ $(\mathrm{r}=0.54 ; \mathrm{p}<0.001)$. None of the subjects in this series had a $T \mathrm{~L}, \mathrm{CO}$,ss value lower than $20 \mathrm{~mL} \cdot \mathrm{min}^{-1} \cdot \mathrm{kPa}^{-1}$. As $T \mathrm{~L}, \mathrm{CO}, \mathrm{ss}$ depends on ventilation, $T \mathrm{~L}, \mathrm{CO}, \mathrm{ss} / V^{\prime} \mathrm{E}$ ratios were calculated. These ratios were correlated to age: $T \mathrm{~L}, \mathrm{CO}, \mathrm{ss} / V^{\prime} \mathrm{E}$ $\left(\mathrm{kPa}^{-1} \times 10^{3}\right)=13.5-0.085 \times$ age $(\mathrm{r}=0.44 ; \mathrm{p}<0.001)$. The linear regression equation of the ratios of $T \mathrm{~L}, \mathrm{CO}, \mathrm{ss}$ to body surface area $(\mathrm{BSA})$ was: $T \mathrm{~L}, \mathrm{CO}, \mathrm{ss} / \mathrm{BSA}\left(\mathrm{mL} \cdot \mathrm{min}^{-1} \cdot \mathrm{kPa}^{-1} \cdot \mathrm{m}^{-1}\right)$ $=121-0.86(\mathrm{r}=0.50 ; \mathrm{p}<0.001)$.

\section{Discussion}

This study shows that blood tensions were not correlated with age in this series of elderly subjects; although, for a given $P \mathrm{a}_{1} \mathrm{CO}_{2}, \mathrm{~Pa}_{\mathrm{a}} \mathrm{O}_{2}$ is slightly lower in elderly than in control young healthy subjects. TL,CO,ss significantly decreases with age and the lowest value observed in this series was $20 \mathrm{~mL} \cdot \mathrm{min}^{-1} \cdot \mathrm{kPa}^{-1}$. As the number of subjects above 90 yrs was relatively small, it could be suggested that some bias in the interpretation of the regression equations of the variables versus age has been introduced; 
however, when the data from subjects above 90 yrs were discarded, although slopes and ordinates of regression equations were slightly altered, the correlation coefficients remained close to those obtained for the whole series.

\section{Blood gas values}

The apparatus used for measuring blood gas values was automatically checked for calibration with calibrated gas mixtures. In addition, whole blood tonometry was performed once a week and samples, the $\mathrm{PO}_{2}$ and $\mathrm{PCO}_{2}$ of which were unknown to the laboratory staff, were analysed. On 21 samples, the relationship between measured $P_{\mathrm{O}_{2}}(\mathrm{y})$ and true $P_{\mathrm{O}_{2}}(\mathrm{x})$ was $\mathrm{y}=1.009 \times+0.03 \mathrm{kPa}$ $(\mathrm{r}=0.992)$. As a consequence, no correction factor was used for the measured values.

It is generally accepted that during life, at least until the age of $70 \mathrm{yrs}, \mathrm{Pa}_{\mathrm{a}} \mathrm{O}_{2}$ progressively decreases leading to a physiological hypoxaemia that has been ascribed to age-induced increase in $V^{\prime} \mathrm{A} / Q^{\prime}$ mismatch [4]. Reference values for $\mathrm{Pa}_{\mathrm{a}_{2}}$ in subjects older than $70 \mathrm{yrs}$ are, however, usually obtained by extrapolation from measurements performed in subjects mainly in the adult age range, with no, or very few, elderly people. For example, Sorbini et al. [5] studied 152 subjects, including 24 above $60 \mathrm{yrs}$ of age with a median age of $71 \mathrm{yrs}$, and only 10 above 70 yrs. In this latter group, mean $P \mathrm{a}, \mathrm{O}_{2}$ was $9.9 \pm 0.6 \mathrm{kPa}$, i.e. lower than in the present series. More recent studies have reported similar values of $P \mathrm{a}, \mathrm{O}_{2}$ (i.e. approximately $10 \mathrm{kPa}$ ) in aged subjects $[6,7]$, whereas higher values (i.e. $11.5 \mathrm{kPa}$ ) close to those in the present study were reported by Conway et al. [8], MellemgaARD [9], Delclaux et al. [10] and CERVERI et al. [11]. Reasons that could account for these discrepancies in the abovementioned studies include differences in the inclusion criteria of the subjects, body position during the measurements, technical and methodological aspects of measurement of blood gas values. The former explanation is difficult to study thoroughly. The latter are discussed in the next paragraphs.

As arterial puncture may induce hyper- or hypoventilation [12], gas exchange ratios were measured during the arterial sample, and in most subjects (77\%) R-values were within the normal range. It should be noted that, in the literature, R-values are not commonly given, and therefore systemic error due to hypo- or hyperventilation during arterial blood withdrawal could be suspected. $\mathrm{Pa}_{2} \mathrm{CO}_{2}$ values can also be taken as a criterion of hypo- or hyperventilation. For SoRBINI et al. [5], mean $\mathrm{Pa}_{\mathrm{a}} \mathrm{CO}_{2}$ in the 24 subjects aged over 60 yrs was $5.3 \pm 0.28 \mathrm{kPa}$, and did not vary whatever the age group. In the present work, mean $P \mathrm{a}, \mathrm{CO}_{2}$ was lower (i.e. $4.6 \pm 0.6 \mathrm{kPa}$ ). If $V^{\prime} \mathrm{A} / Q$ heterogeneity in aged subjects was moderate, this difference in $\mathrm{Pa}, \mathrm{CO}_{2}$ (i.e. $0.7 \mathrm{kPa}$ ) should be accompanied by a similar but opposite difference in $P \mathrm{a}_{1} \mathrm{CO}_{2}$ [13]. As a consequence, the higher $\mathrm{Pa}, \mathrm{O}_{2}$ value observed in the present study may only reflect a difference in ventilation between the two populations. However, unlike young healthy subjects (table 3 ), $P \mathrm{a}, \mathrm{O}_{2}$ in elderly subjects with low $\mathrm{Pa}_{\mathrm{a}} \mathrm{CO}_{2}$ was not higher than that in elderly subjects with higher $P \mathrm{a}, \mathrm{CO}_{2}$. Thus, it is likely that hyperventilation worsens the distribution of $V^{\prime} \mathrm{A} / Q^{\prime}$ in these subjects. This hypothesis seems to be supported by the fact that both $P \mathrm{~A}-\mathrm{a}, \mathrm{O}_{2}$ and $P \mathrm{a}-\mathrm{A}, \mathrm{CO}_{2}$, are higher in old people than in young subjects. For example,
KANBER et al. [14] have reported a twofold increase in $\mathrm{PA}_{\mathrm{A}-\mathrm{a}, \mathrm{O}_{2}}$ between 34 and $72 \mathrm{yrs}$ of age.

Another possible factor which could alter the blood gas values is related to the resistance through which the subjects are breathing. In the present study, the subjects breathed through the mouth and were relieved from nasopharyngeal resistances; but, simultaneously, they breathed through a valve chamber and a PTG, the overall pressure loss of which for a $0.25 \mathrm{~L} \cdot \mathrm{s}^{-1}$ flow, was $0.35 \mathrm{hPa}$, i.e. the resistance was $1.4 \mathrm{hPa} \cdot \mathrm{L}^{-1} \cdot \mathrm{s}$. Both effects could compensate one for the other. Changes in resistance alter the pattern of intra-alveolar pressure. A slight increase in end-expiratory pressure could avoid airway closure and improve gas exchange. However, in most studies, the route of breathing is not indicated and it is, therefore, difficult to assess its effect on $\mathrm{Pa}, \mathrm{O}_{2}$. It is noteworthy that many freely breathing subjects change their route of breathing during the arterial puncture, which could be a cause of scatter of normal $\mathrm{Pa}, \mathrm{O}_{2}$, at least in elderly people.

Changes in body position induce alterations in $\mathrm{Pa}, \mathrm{O}_{2}$, due to changes in the $V^{\prime} \mathrm{A} / Q^{\prime}$ distribution partially linked to the direct effect of gravity [15], but also to changes in lung volume and, therefore, closing volume [16]. In young subjects, the distribution of $V^{\prime} \mathrm{A} / Q^{\prime}$ is less heterogeneous in a supine than in an erect posture, as in older subjects this phenomenon is hindered by the effect of airway closure in the dependent part of the lung, decreasing $V^{\prime} \mathrm{A} / Q^{\prime}$ values. In the long-term, a supine position may lead to atelectasis. Therefore, one possible explanation for the discrepancies among results in the literature is that data have been obtained in different postures. In fact, the data of Sorbini et al. [5] were obtained in supine subjects and the reported decrease in $\mathrm{Pa}, \mathrm{O}_{2}$ with age was sharp; whilst in the studies by Delclaux et al. [10] and CeRveri et al. [11], and in the present study data were obtained in the sitting position and there was no decline in $\mathrm{Pa}, \mathrm{O}_{2}$ with age in elderly people. Therefore, in clinical practice, attention should be paid to body position when interpreting blood gas values in elderly subjects.

\section{CO transfer in the elderly}

The decline in TL,CO with age is a well-established relationship, starting very early in adult life. In young subjects aged 20-40 yrs, TL,CO,ss/BSA is about 60 $\mathrm{mL} \cdot \mathrm{min}^{-1} \cdot \mathrm{kPa}^{-1} \cdot \mathrm{m}^{-2}$, according to the results of FILLEY et al. [17] Bates and PeArCe [18] and GuÉNARD et al. [19]. In the present study, the value of $T \mathrm{~L}, \mathrm{CO}, \mathrm{ss} / \mathrm{BSA}$ was about $35 \mathrm{~mL} \cdot \mathrm{min}^{-1} \cdot \mathrm{kPa}^{-1} \cdot \mathrm{m}^{-2}$, corresponding to approximately one half that observed in young subjects. The result is in agreement with that of GEORGES et al. [20], who used the single-breath method. The decrease in single-breath $T_{\mathrm{L}, \mathrm{CO}}\left(T_{\mathrm{L}}, \mathrm{CO}, \mathrm{sb}\right)$ is linear for CRAPO and Morris [1], and Muiesan et al. [2]. GeOrges et al. [20] have reported a nonlinear decrease in $T \mathrm{~L}, \mathrm{CO}, \mathrm{sb}$ with age, which has been ascribed to the fact that the rate of decline in the pulmonary capillary blood volume $\left(Q_{\mathrm{c}}\right)$ increases sharply above the age of $60 \mathrm{yrs}$.

In the present study, we could not measure the two components of the lung transfer capacity factor, i.e. diffusing capacity of the alveolocapillary membrane $(D \mathrm{~m})$ and $Q_{\mathrm{c}}$. However, if one assumes that the reduction in the two components is similar, the lowest $T_{\mathrm{L}}, \mathrm{CO}$ value observed in the present series corresponds to approximately 40 
$\mathrm{mL} \cdot \mathrm{min}^{-1} \cdot \mathrm{kPa}^{-1}$ and $12 \mathrm{~mL}$ for $D \mathrm{~m}$ and $Q_{\mathrm{c}}$, respectively, in agreement with the calculated lowest value of $Q_{\mathrm{c}}$, i.e. $13 \mathrm{~mL}$ from the data of Georges et al. [20]. The following structural changes may account for these functional alterations. On the one hand, the density of lung capillaries decreases with age [21], although data in subjects older than $60 \mathrm{yrs}$ are still lacking. Moreover, there is evidence that pulmonary capillary pressure increases with age, at least during moderate muscular exercise [22], which suggests that the recruitment of pulmonary capillaries is also limited in elderly subjects. On the other hand, according to VERBEKEN et al. [23], the "senile lung" is characterized by "a homogeneous enlargement of the alveolar airspaces, without fibrosis or destruction of their walls". This enlargement is associated with a reduction in surface, which reduces $D \mathrm{~m}$. Moreover, $D \mathrm{~m}$ could be further reduced by the increased thickness of the gas phase. Graham et al. [24] have shown that TL,CO,sb depends on the duration of the apnoea in patients with obstructive diseases, either asthma or emphysema, and that this dependency is a function of the overdistension of the lungs, i.e. alveolar spaces. Therefore, a limitation of the diffusion of $\mathrm{CO}$ in the gas phase is also likely to contribute to the decrease in $D \mathrm{~m}$ in elderly people.

The decrease in $T \mathrm{~L}, \mathrm{CO}$ value with age may indicate that $\mathrm{O}_{2}$ transport could be diffusion-limited in elderly subjects. The lowest value of $T \mathrm{~L}, \mathrm{CO}$ observed in this series corresponds to very low values of $D \mathrm{~m}$ (approximately $40 \mathrm{~mL} \cdot \mathrm{min}^{-1} \cdot \mathrm{kPa}^{-1}$ ) and $Q_{\mathrm{c}}$ (about one fifth of that in young adults, i.e. $15 \mathrm{~mL}$ ). These figures appear critical for $\mathrm{O}_{2}$ transport $[25,26]$, if not at rest, at least when oxygen consumption is increased, such as during muscular activity or fever. In conclusion, although there was no correlation between blood gas values and age in this series of elderly subjects, the decrease in transfer capacity of the lung for carbon monoxide suggests that oxygen transport may be diffusion-limited in ageing.

Acknowledgements: The authors appreciate the assistance of P. Vaïda for his participation in the experiments, and J-P. Pivetaud for recruiting and examining the subjects. They thank all the subjects for their kind co-operation.

\section{References}

1. Crapo RP, Morris AH. Standardized single-breath normal values for carbon monoxide diffusing capacity. Am Rev Respir Dis 1981; 123: 185-189.

2. Muiesan C, Sorbini CAA, Grassi V. Respiratory function in the aged. Bull Eur Physiopathol Respir 1971; 7: 973-1009.

3. O.Boezen HM, Schouten JP, Postma DC, Rijcken B. Distribution of peak expiratory flow variability by age, gender and smoking habits in a random population sample aged 20-70 yrs. Eur Respir J 1991; 7: 1811-1820.

4. Wagner PD, Laravuso RB, UHL RR, West JB. Continuous distribution of ventilation-perfusion ratios in normal subjects breathing air and $100 \% \mathrm{O}_{2}$. J Clin Invest 1974; 54 : 54-68.

5. Sorbini CAA, Grassi V, Solinas SE, Muiesan G. Arterial oxygen tension in relation to age in healthy subjects. Respiration 1968; 25: 3-13.

6. Knudson RJ. How aging affects the normal adult lung. J Respir Dis 1981; 2: 74-84.

7. Redhammer R, Mihalec L, Chowan L. Changes of gas exchange parameters with age. Am Rev Respir Dis 1990; 141: A852.

8. Conway CM, Payne JP, Tomlin PJ. Arterial oxygen tensions of patients awaiting surgery. Br J Anaesth 1965; 37: 405-408.

9. Mellemgaard K. The alveolar-arterial oxygen difference: its size and components in normal man. Acta Physiol Scand 1966; 67: 10-20.

10. Delclaux B, Orcel B, Housset B, Whitelaw WA, Derenne JP. Arterial blood gases in elderly persons with chronic obstructive pulmonary disease (COPD). Eur Respir $J$ 1994; 7: 856-861.

11. Cerveri I, Zoia MC, Fanfulla F, et al. Reference values of arterial oxygen tension in the middle-aged and elderly. Am J Respir Crit Care Med 1995; 152: 934-941.

12. Cinel D, Markwell K, Lee R, Szidon P. Variability of the respirator gas exchange ratio during arterial puncture. Am Rev Respir Dis 1991; 113: 217-218.

13. West JB. Ventilation-perfusion inequality and overall gas exchange in computer models of the lung. Respir Physiol 1969; 7: 88-110.

14. Kanber GJ, King FW, Eshcar YR, Sharp JT. The alveolar-arterial oxygen gradient in young and elderly men during air and oxygen breathing. Am Rev Respir Dis 1968; 97: 376-380.

15. Amis TC, Jones HA, Hughes JMB. Effect of posture on inter-regional distribution of pulmonary perfusion and $V^{\prime} \mathrm{A} / Q^{\prime}$ ratios in man. Respir Physiol 1984; 56: 169-182.

16. Holland J, Milic-Emili J, Macklem PT, Bates DV. Regional distribution of pulmonary ventilation and perfusion in elderly subjects. J Clin Invest 1968; 17: 81-92.

17. Filley G, MacIntosh DJ, Wright GW. Carbon monoxide uptake and pulmonary diffusing capacity in normal subjects at rest and during exercise. J Clin Invest 1954; 33: 530-539.

18. Bates DV, Pearce JF. The pulmonary diffusing capacity: a comparison of methods of measurement and a study of the effect of body position. J Physiol 1956; 132: 232-238.

19. Guénard H, Chaussain M, Lebeau C. Respiratory gas exchange under normobaric helium-oxygen breathing at rest and during muscular exercise. Bull Eur Physiopathol Respir 1978; 14: 417-429.

20. Georges R, Saumon G, Loiseau A. The relationship of age to pulmonary membrane conductance and capillary blood volume. Am Rev Respir Dis 1978; 117: 1069-1078.

21. Butler C, Kleinerman J. Capillary density: alveolar diameter, a morphometric approach to ventilation and perfusion. Am Rev Respir Dis 1970: 102: 886-894.

22. Ersham R, Perruchoud DA. Oberholzer M, Burkart F, Herzog H. Influence of age on pulmonary haemodynamics at rest and during supine exercise. Clin Sci 1983; 65: 653-660.

23. Verbeken EK, Cauberghs M, Mertens I, Clement J, Lauweryns JM, Van de Woestijne KP. The senile lung: comparison with normal and emphysematous lungs. 1 . Structural aspects. 2. Functional aspects. Chest 1992; 101: 793-809.

24. Graham BL, Mink JT, Cotton DJ. Effect of breath-hold time on $D$ L,CO (sb) in patient with airway obstruction. J Appl Physiol 1985; 58: 1319-1325.

25. Wagner PD, West JB. Effect of diffusion impairment on $\mathrm{O}_{2}$ and $\mathrm{CO}_{2}$ tissue courses in pulmonary capillaries. J Appl Physiol 1972; 33: 62-71.

26. Piiper J, Scheid P. Blood gases equilibration in lungs. In: West JB, ed. Pulmonary Gas Exchange. Vol. I. Ventilation, Blood Flow and Diffusion. San Francisco, New York, Academic Press, 1980; pp. 131-171. 